\title{
KHALWAT DALAM PERSPEKTIF HUKUM ISLAM DAN HUKUM POSITIF
}

\author{
Bukhari \\ (Dosen Fakultas Syariah IAIN Lhokseumawe)
}

\begin{abstract}
The existence of a man and woman who have no kinship so that it is lawful to marry her, in a lonely place without being ac companied by a mahram of the male or female side. This khalwat is a crime that is not subject to hudud punishment and kafarah punishment. This form of khalwat crime is included in the category of ta'zir finger whose number of punishment is not limited. In the Qur'an and Sunnah this khalwat act is highly reproached, but not clearly regulated in the Qur'an and Sunnah. So this act can be entered into the ta'zir group. All deeds that should (need) be forbidden to fulfill the common good (community). This prohibition must necessarily be made on the basis of community agreement / consensus in ways that are considered eligible. In North Aceh, the khalwat actors who are close to the power are hard to touch with the law, it is not surprising to all of us to remember that the law in this country is not yet the commander but the law is merely a bargaining position in everyday life.
\end{abstract}

Keywords: khalwat, Islamic law and positive law.

Abstrak: Keberadaan pria dan wanita yang tidak memiliki hubungan kekeluargaan sehingga sah untuk menikahinya, di tempat yang sepi tanpa ditemani oleh mahram dari sisi pria atau wanita. Khalwat ini adalah kejahatan yang tidak dikenakan hukuman hudud dan hukuman kafarah. Bentuk kejahatan khalwat ini termasuk dalam kategori jari ta'zir yang jumlah hukumannya tidak terbatas. Dalam Al Qur'an dan Sunnah, tindakan khalwat ini sangat dicela, tetapi tidak diatur dengan jelas dalam Alquran dan Sunnah. Jadi tindakan ini bisa dimasukkan ke dalam kelompok ta'zir. Semua perbuatan yang seharusnya (perlu) dilarang untuk memenuhi kepentingan bersama (komunitas). Larangan ini harus dilakukan atas dasar kesepakatan / konsensus komunitas dengan cara yang dianggap memenuhi syarat. Di Aceh Utara, aktor khalwat yang dekat dengan kekuasaan sulit disentuh dengan hukum, tidak mengherankan bagi kita semua untuk mengingat bahwa hukum di negara ini belum menjadi komandan tetapi hukum hanyalah posisi tawar. dalam kehidupan sehari-hari.

Kata kunci: khalwat, hukum Islam dan hukum positif.

\section{PENDAHULUAN}

Zaman modern seperti ini masyarakat sosial sering dihadapkan dengan masalah-masalah yang kerap menodai agama dengan pergaulan yang tanpa dibatasi dengan aturan atas hukum yang mengikat kepada penganut agama. Sehingga menjadi sebuah keprihatinan bagi kita umat yang beragama Islam dengan kebiasaan orang yang tidak peduli dengan aturan yang dalam hal ini menurutnya sebagai 
penghalang atas apa yang ingin dilakukan atau dengan kata lain untuk menuruti keinginan hawa nafsunya.

Agama dan hukum positif sama sekali tidak melarang hambanya untuk melakukan sesuatu yang jika hal itu tidak akan merusak atau menjadi mudharat bagi yang membangkang. Betapa banyak orang-orang yang melakukan hubungan seks secara bebas terjangkit oleh penyakit yang mematikan, adakah renungan tentang semua itu, itu adalah tanda-tanda kebesaran Allah bagi orang yang berakal. Hasrat untuk menyalurkan kebutuhan biologis merupakan fitrah manusia, tetapi menyalurkannya perlu diatur. Agama islam telah mengatur batasan-batasan yang boleh dilakukan, sehingga tudak terjadi penyelewengan hukum. Agama islam telah menetapkan hal tersebut melalui jalan perkawinan yang sah.

Salah satu aspek ajaran Islam yang menempati posisi penting dalam pandangan umat Islam, karena ia merupakan manifestasi paling tipikal dan paling konkrit dari Islam sebagai sebuah agama. Sedemikian pentingnya hukum Islam dalam skema doktrinal Islam sehingga seorang orientalis, Joseph Schacht menilai bahwa "adalah mustahil memahami Islam tanpa hukum Islam. ${ }^{1}$

Mengenai praktek penegakan Qanun khalwat terhadap pelaku pelanggaran khalwat di Aceh. Ada tiga Qanun yang berhubungan Jinayah yang telah disahkan pemerintah Aceh pada tahun 2003 yaitu Qanun Khamar dan Sejenisnya, Maisir (Judi), Khalwat (Mesum). Penegakannya dari tahun 2004 sampai dengan 2008, melalui keputusan

1 Idris Ramulyo, Asas-asas Hukum Islam. (Jakarta: Sinar Grafika.2004), hal. 2
Mahkamah Syar'iyah dengan hukuman cambuk atau denda. Sejak 2009 hingga saat ini, khusus penegakan qanun khalwat cenderung diselesaikan dengan pengadilan adat masyarakat setempat. Pertanyaan penting di sini adalah apa faktor penghambat penegakan qanun khalwat di Aceh; apa implikasi dari tidak ditegakkan sistem hukum dalam pelaksanaan Qanun khalwat di Aceh, dan menggunakan sistem hukum apa dalam penegakan Qanun khalwat di Aceh.

Manfaat pribadi agar seseorang tidak melakukan perbuatan yang mengarah pada perbuatan zina yang dilarang oleh agama dan mengakibatkan dosa dan siksa di kemudian hari. Sementara manfaat bagi orang lain adalah melindungi masyarakat dari berbagai bentuk kegiatan dan atau perbuatan yang merusak kehormatan. Sebagaimana dikemukakan pada Qanun khalwat, tujuan larangan khalwat salah satunya adalah melindungi masyarakat sedini mungkin dari melakukan perbuatan yang mengarah kepada zina dan merusak kehormatan. Agaknya semakin trend saja tentang perzinahan di kalangan masyarakat. Tidak pandang itu orang awam maupun kalangan elit, baik itu yang masih sendiri ataupun yang sudah mempunyai keluarga. Bahkan kalangan remaja pun mulai coba-coba. Hal itu bisa terjadi bisa dikarenakan beberapa faktor yang bisa mengakibatkan hal itu terjadi. Diantaranya kurangnya pengawasan dari pihak keluarga, bisa juga karena benteng dari iman di dalam masingmasing individu masih lemah. Oleh karena itu butuh pengawasan dan fondasi agama yang kuat agar kita terhindar dari perbuatan keji tersebut. 
Sikap tegas dari pemerintah pun diperlukan guna mencegah meluasnya praktek-praktek prostitusi yang berkembang di masyarakat.

Penegakan syariat Islam di Aceh Utara khususnya dalam bidang khalwat masih jauh panggang dari api, artinya budaya khalwat masih menjamur dalam kehidupan masyarakat, bahkan kebanyakan orang tua sangat mendukung anaknya untuk berbuat khalwat, ini di iringi saat anak dijemput oleh orang yang bukan non muhrim, para orang tua memberi ijin asal jangan pulang terlalu malam, ada juga anak gadisnya yang pulang besok pagi mereka tenang-tenang saja seakan tidak terjadi apa-apa.

Berdasarkan penjelasan di atas penulis merasa penting untuk membahas lebih komprehensif mengenai praktek pelanggaran meusum khususnya di Aceh Utara yang akan menjadi titik fokus dari pembahasan ini, yakni: bagaimanakah proses hukum terhadap khalwat yang terjadi dalam kehidupan masyarakat.

\section{KHALWAT}

Khalwat secara etimologis 'khulwah' berasal dari kata khala' yang berarti 'sunyi' atau 'sepi'. Khalwat adalah istilah yang digunakan untuk keadaan tempat seseorang yang tersendiri dan jauh dari pandangan orang lain. Istilah khalwat dapat mengacu kepada hal-hal negatif, yaitu seorang pria dan seorang wanita berada di tempat sunyi dan sepi dan terhindar dari pandangan orang lain, sehingga sangat memungkinkan mereka berbuat maksiat. ${ }^{2}$ Dalam pemakaiannya, istilah

${ }^{2}$ Abdul Aziz Dahlan, Ensiklopedi Hukum Islam (Jakarta: Ichtiar Baru van Hoeve, 1996), hal. 898 berkonotasi ganda, positif dan negatif. Dalam makna positif, khalwat adalah menarik diri dari keramaian dan menyepi untuk mendekatkan diri kepada Allah. Dalam arti negatif, khalwat berarti perbuatan berdua duaan di tempat sunyi atau terhindar dari pandangan orang lain antara seorang pria dan seorang wanita yang bukan mukhrim dan tidak terikat perkawinan. ${ }^{3}$

Dalam terminologi hukum Islam, khalwat didefinisikan dengan keberadaan seorang pria dan wanita yang tidak ada hubungan kekerabatan sehingga halal menikahinya, di tempat yang sepi tanpa didampingi oleh mahram dari pihak laki-laki atau perempuan. ${ }^{4}$ Berdasarkan pengertian di atas bahwa khalwat antara seorang pria dengan seorang wanita yang bukan muhrimnya tanpa disertai oleh mahram maka hukumnya haram, meskipun keduanya tidak melakukan hal-hal yang melanggar ajaran Islam, sebab larangan tersebut ditujukan kepada perbuatan khalwatnya. Sebagaimana yang telah ditegaskan dalam firman Allah Q.S AlIsra YANG Artinya: Dan janganlah kamu mendekati zina; Sesungguhnya zina itu adalah suatu perbuatan yang keji. dan suatu jalan yang buruk. (Q.S

${ }^{3} \mathrm{Al}$ Yasa' Abubakar, Marah Him., Hukum Pidana Islam di Nanggroe Aceh Darusalam, (Dinas Syari'at Islam Nanggroe Aceh Darussalam, 2006), hal. 80

${ }^{4}$ Adapun mahram di dalam Al-Quran adalah ibu, anak perempuan, saudara perempuan, saudara bapak yang perempuan, saudara ibu yang perempuan, anak perempuan dari saudara laki-laki,anak perempuan dari saudara perempuan, ibu yang menyusui, saudara perempuan sepenyusuan, mertua, anak perempuan tiri yang ibunya telah digauli, menantu (istri dari anak kandung), dan saudara kandung istri (QS. 4. 23). 
Al-Isra, ayat 32).

Ayat di atas mengharamkan dua hal sekaligus: (a) zina; dan (b) segala perilaku yang mendekati perbuatan zina termasuk di antaranya adalah berduaan antara dua lawan jenis yang bukan mahram yang disebut dalam istilah bahasa Arab dengan khalwat dengan yang selain mahram.

Dalam Qanun Provinsi Nanggroe Aceh Darussalam, Nomor 14 Tahun 2003 Bab I Pasal 1 dijelaskan bahwa, khalwat atau mesum adalah perbuatan bersunyisunyi antara dua orang mukallaf atau lebih yang berlainan jenis yang bukan mahram atau tanpa ikatan perkawinan. Akan tetapi, khlawat/mesum tidak hanya terjadi di tempat-tempat tertentu yang sepi dari penglihatan orang lain, tetapi dapat juga terjadi di tengah keramaian atau di jalanan atau di tempat-tempat umum lainnya, dimana laki-laki dan perempuan berasyikasyikan tanpa ikatan nikah. ${ }^{5}$

Delik pidana khalwat menurut Qanun Nomor 14 Tahun 2003 Tentang Khalwat (Mesum) adalah: "Perbuatan bersunyi-sunyi antara dua orang mukallaf atau lebih yang berlainan jenis yang bukan muhrim atau tanpa ikatan perkawinan". (Pasal 1 ayat (1) Qanun Nomor 14 Tahun 2003).

Di sini dapat diketahui bahwa syarat khalwat adalah dilakukan oleh dua orang mukallaf yang berlainan jenis kelamin (laki-laki dan perempuan), bukan suami istri dan halal menikah, (maksudnya bukan orang yang mempunyai hubungan muhrim). Dua

5 Sri Suyanta, Buku Pelaksanaan Panduan Syari'at Islam Untuk Remaja dan Mahasiswa. Cet, II, (Banda Aceh: Dinas Syari'at Islam Provinsi Nanggroe Aceh Darussalam 2008), hal. 279-280. orang tersebut dianggap melakukan khalwat kalau mereka berada pada suatu tempat tertentu yang memungkinkan terjadinya perbuatan maksiat di bidang seksual atau berpeluang pada terjadinya zina.

Mengenai ketentuan 'Uqubat terhadap pelaku pelanggar terhadap Qanun khalwat tersebut diatur sebagai berikut Pasal 22 berbunyi :

- Setiap orang yang melanggar ketentuan sebagaimana dimaksudkan dalam Pasal 4 diancam dengan "Uqubat ta'zir berupa dicambuk paling tinggi 9 (Sembilan) kali, paling rendah 3 (tiga) kali dan/atau denda paling banyak Rp. 10.000.000,- (sepuluh juta rupiah), dan paling sedikit $\mathrm{Rp}$. 2.500.000,- (dua juta lima ratus ribu rupiah).

- Setiap orang yang melanggar ketentuan yang melanggar ketentuan sebagaimana yang dimaksud Pasal 5 diancam dengan 'Uqubat Ta'zir berupa kurungan paling lama 6 (enam) bulan, paling singkat 2 (dua) bulan dan/atau denda paling banyak Rp.15.000.000,- (lima belas juta rupiah), paling sedikit Rp. 5.000.000,- (lima juta rupiah).

- Pelanggar terhadap larangan sebagaimana dimaksud dalam Pasal 5 adalah jarimah ta'zir.

- Pasal 24 berbunyi: pengulangan pelanggaran terhadap ketentuan sebagaimana dimaksud dalam Pasal 22, 'Uqubatnya dapat ditambah1/3 (sepertiga) dari 'Uqubat maksimal”.

Dengan demikian terhadap pelaku yang terbukti kembali melakukan hal yang sama padahal dia sudah pernah 
dihukum untuk kejahatan serupa maka hukumannya dapat ditambah 1/3 lagi dari hukuman maksimal menjadi 12 kali cambuk. Begitu pula denda dapat ditambah 1/3 dari ketentuan maksimal.

Pasal 25 berbunyi, pelanggaran terhadap ketentuan sebagaimana dimaksudkan dalam Pasal 5 dan 6 :

a. Apabila dilakukan oleh badan hukum/badan usaha, maka 'Uqubatnya jatuh kepada penanggung jawab.

b. Apabila ada hubungan dengan kegiatan usahanya, maka selain sanksi 'Uqubat sebagaimana dimaksud dalam Pasal 22 ayat (1) dan (2) dapat juga dikenakan 'Uqubat administratif dengan mencabut atau membatalkan izin usaha yang diberikan.

Dari ketentuan hukuman ini, telihat bahwa orang yang melakukan khalwat/mesum sekitarnya terbukti, dapat dijatuhi hukuman cambuk paling banyak sembilan kali, dan paling sedikit tiga kali. Hukuman ini ditambah atau ditukar dengan hukuman lain yaitu berupa denda paling banyak sepuluh juta rupiah, dan paling sedikit dua juta lima ratus ribu rupiah. Sedangkan orang yang memberikan fasilitas, membantu atau melindungi orang lain yang melakukan perbuatan mesum apabila terbukti dapat dijatuhkan hukuman paling lama enam bulan kurungan, paling sedikit dua bulan kurungan. Dikenakan denda paling banyak lima belas juta rupiah, dan paling sedikit lima juta rupiah.

Ditinjau dari segi hukum kategori ta'zir didasarkan pada ijma' karena berkaitan dengan kekuasaan negara untuk melakukan penegakan hukum terhadap kasus-kasus ta'zir secara sederhana dapat disebutkan sebagai berikut:

1. Kejahatan yang tidak termasuk ke dalam hudud dan jinayat atau qisash

2. Atas diskresi penguasa dan hakim

3. Didasari pada ketentuan umum syari'at Islam, kepentingan publik, tanpa penyimpangan atau penyalahgunaan

4. Kejahatan berhubungan dengan hudud tetapi dengan alasan harus dikecualikan (seperti pencurian ringan, percoabaan zina, ada keraguan dalam bukti), perbuatan yang dilarang syari'ah Islam tanpa hukuman tertentu di dunia (seperti makan babi, riba, mengurangi timbangan, dan sebagainya), perbuatan lain yang merugikan kepentingan publik atau ketertiban umum atau hak-hak individu (sepertikejahatan ekonomi, pemalsuan)

Dalam al-Qur'an dan Sunnah perbuatan khalwat ini sangatlah dicela, tetapi tidak diatur secara jelas perihal hukumannya di dalam al- Qur'an dan Sunnah. Jadi perbuatan ini dapat dimasukkan ke dalam kelompok ta'zir. Semua perbuatan yang harus dilarang guna memenuhi kemaslahatan masyarakat. Pelarangan ini tentu harus dibuat berdasarkan kesepakatan atau musyawarah masyarakat dengan caracara yang dianggap memenuhi syarat. ${ }^{6}$

Untuk menentukan bahwa perbuatan khalwat merupakan sebuah kejahatan dalam ruang lingkup ta'zir,

6 Al Yasa' Abubakar, Penerapan Syari'at Islam di Indonesia; Antara Peluang Dan Tantangan, (Jakarta: Globamedia Cipta Publishing, 2004), hal. 127 
maka harus diketahui hal-hal yang menyangkut dengan unsur-unsurnya. Dalam hukum pidana Islam secara garis besar dapat dibagi kepada dua, yaitu unsur-unsur dasar (umum) dan unsurunsur khusus. Adapun unsur-unsur dasar mencakup sebagai berikut: ${ }^{7}$

1. Al-Rukn al-Syar'i (unsur hukum atau legal element), yaitu ketentuan yang jelas untuk melarang suatu perbuatan yang merupakan kejahatan dan menentukan hukum atasnya

2. Al-Rukn al-Madi (unsur materil atau essential element), yaitu berupa perbuatan, baik perbuatan aktif (komisi) perbuatan pasif (omisi).

3. Al-Rukn al-Adabi (unsur budaya/moril/kultural element) yang meliputi kedewasaan, dapat bertanggung jawab dan dapat dipersalahkan pada diri si pelaku.

Sementara unsur khusus dari kejahatan berbeda-beda dengan berbedanya sifat kejahatan. Ini dibicarakan dalam membahas kejahatan-kejahatan tertentu. Karena itu, satu tindak pidana dapat memiliki unsur yang khusus yang tidak ada pada tindak pidana lainnya. Berdasarkan pemaparan unsur-unsur dasar (umum) dan unsur-unsur khusus yang telah disebutkan di atas, maka penentuan tentang perbuatan khalwat dalam ruang lingkup itu dapat dikatakan sudah terindikasikan dan tergolong ke dalam kejahatan yang patut dilarang dan dapat ditentukan hukumannya bagi pelaku

${ }^{7}$ Nasrullah, Konsep Ancaman pidana Ta'zir Dalam Fiqih Syafiiyyah (Analisis Terhadap Qanun NAD No. 14 Tahun 2003), (Banda Aceh: Program Pasca Sarjana IAIN AR-RANIRY, 2006), hal. 33 perbuatan itu (khalwat).

Sebagai perbuatan (kejahatan) yang patut dilarang, maka dalam istilah lain perbuatan khalwat dikatakan sebagai "dilarang dalam berbuat setiap maksiat, baik kepada Allah Swt maupun manusia". Para ulama telah sepakat bahwa meninggalkan hal yang wajib dan melakukan hal yang haram adalah maksiat. Setiap maksiat yang sanksinya tidak ditentukan oleh Al-Qur'an dan al Sunnah sanksinya adalah ta'zir. Oleh karena itu, perbuatan khalwat adalah termasuk dalam setiap perbuatan maksiat dan patut untuk dilarang oleh setiap pihak tanpa membiarkan setiap orang melakukannya pada setiap saat dan tempat.

\section{KHALWAT DALAM PERSPEKTIF SOSIOLOGI HUKUM}

Seperti yang terjadi pada realita di Aceh Utara, pelaku khalwat yang dekat dengan kekuasaan sulit sekali untuk disentuh dengan hukum, hal ini tidaklah menghenrankan kita semua mengingat hukum di negeri ini belumlah menjadi panglima tapi hukum hanyalah sebagai posisi tawar menawar (bargaining position) dalam kehidupan sehari-hari. Hal ini memberikan dampak negatif terhadap pelaksanaan pencegahan khalwat karena hukum hanya diberlakukan bagi masyarakat bawahan saja.

Dalam hal ini, untuk menjaga stabilitas perlu menetapkan aturanaturan yang dapat menciptakan ketertiban atau ketrentraman (semacam Undang-undang atau qanun yang bersumber dari kehendak pemerintah baik ketentuan maksimal atau minimal), secara individu atau kolektif dengan maksud untuk merubah keadaan 
masyarakat, mengganti ikatan-ikatan, dan memperbaharui hubunganhubungannya baik bertujuan demi kemaslahatan masyarakat atau kemaslahatan secara menyeluruh. Dengan kata lain, penetapan perbuatan menurut jenis pelanggaran dan sanksisanksinya adalah dimaksudkan untuk mempertahankan dan memelihara keberadaan serta kelangsungan hidup masyarakat, khususnya masyarakat Islam. Sebab, jika seseorang melakukan perbuatan buruk (terlarang), maka ia akan kembali pada kehidupan untuk kedua kalinya sampai ia mendapatkan balasan setimpal atas apa yang telah dilakukan. Oleh karena itu, menjamin keamanan dari kebutuhan-kebutuhan hidup merupakan tujuan pertama dan utama dari syariah. ${ }^{8}$

Larangan khalwat merupakan pencegahan dini bagi perbuatan zina. Larangan ini berbeda dengan beberapa jarimah lain yang langsung kepada zat perbuatan itu sendiri, seperti larangan mencuri, minum khamar, dan maisir. Larangan zina justru dimulai dari tindakantindakan yang mengarah kepada zina. Hal ini mengindikasikan betapa Islam sangat memperhatikan kemurnian nasab seseorang anak manusia.

Dalam beberapa hadist, Nabi menunjukkan batas-batas pergaulan antara laki-laki dan perempuan yang bukan muhrimnya. ${ }^{9}$ Akan tetapi, nilainilai etika yang ditawarkan Islam tersebut, di zaman modern ini mendapat tantangan yang serius dari budaya sekuler yang serba permisif yang pada umumnya datang dari Barat. Budaya

\footnotetext{
${ }^{8}$ Ibid, hal. 103

${ }^{9} \mathrm{Al}$ Yasa' Abubakar dan Marah Him, Ibid, hal. 81.
}

sekuler adalah budaya yang lahir dari aliran filsafat sekulerisme yang memisahkan nilai-nilai agama dengan nilai-nilai duniawi. Manusia bebas sebebas-bebasnya menetukan urusan dunianya termasuk dalam hal hubungan laki-laki dan perempuan.

Dalam budaya masyarakat Barat, hubungan antara laki-laki dan perempuan tidak mesti diikat dengan suatu tali perkawinan, Seorang laki-laki dan perempuan dapat hidup bersama tanpa ikatan perkawinan, bahkan sampai si perempuan melahirkan anak. Akibat dari cara berpikir seperti ini, maka di Barat berkembang berbagai pemikiran yang mendukung kebebasan sebagaimana digambarkan di atas.

Meski budaya barat nyata-nyata bertentangan dengan budaya Islam, tetapi dalam kenyataan budaya barat ini berkembang dengan baik di negaranegara Timur yang pada umumnya religius tak terkecuali dunia Islam. Perkembangan budaya barat di dunia Islam juga dipengaruhi oleh sistem politik dunia Islam yang mengikut sepenuhnya kepada barat dari sistem Politik, kepengikutan itu akhirnya merembes ke wilayah- wilayah lain seperti, wilayah sosial, budaya, hukum, dan sebagainya. Dalam bidang hukum, khususnya yang diterapkan di Indonesia menganut sepenuhnya sistem hukum Barat yang melegalkan pergaulan bebas yang disebut Islam sebagai perzinaan. Akibatnya dalam bidang budaya masyarakat Indonesia modern, juga akrab dengan produk-produk budaya Barat yang mendukung pergaulan bebas seperti, pacaran (dating), tunangan, free sex, sumon liven (kumpul kebo) dan sebagainya. 


\section{PERANAN SOSIOLOGI HUKUM DALAM MEMBERANTASKAN PELAKU KHALWAT}

Adanya Undang-Undang atau Qanun tentang khalwat di Aceh bukan hal yang baru bagi rakyat Aceh, karena secara historis daerah yang dikenal ' Serambi Mekkah' itu kehidupan beragama dan nuansa-nuansa Islam sudah begitu kental dan mengakar dan hukum Islam telah diterapkan sejak masih berbentuk kerajaan. Namun di sisi lain terdapat indikasi apatisme dan pesimisme masyarakat Aceh terhadap penerapan Syariat Islam di Aceh. Hal ini terlihat dari sikap setengah hati dan komuflase pemerintah pusat dalam memberikan otonomi dan kewenangan kepada pemerintah daerah, baik dalam cakupan bidang penerapan Syariat Islam yang terbatas maupun larangan pemberian hukuman yang sejalan dengan Syariat Islam. ${ }^{10}$

Para aparat penegak hukum dalam melaksanakan tugasnya haruslah berpegang pada hukum yang berlaku, tidak membedakan antara satu dengan yang lain dalam artian hukum itu berlaku sama untuk semua lapisan masyarakat tanpa membedakan pangkat dan jabatan. Hal ini relevan dengan teori yang dikemukakan oleh Karl Marx dalam buku Sosiologi Suatu Pengantar yang menganggap konflik antar kelas sosial menjadi intisari perubahan masyarakat. Dari teori tersebut dapat dipahami bahwasanya penerapan hukum yang membedakan kelas dapat mempengaruhi perubahan sosial dalam

10 M. Djali Yusuf, Perekat Hati yang Tercabik: jawaban atas Dinamika persoalan, Refleksi sosial Aceh, dan sebuah kesadaran untuk Masa Depan, ( Jakarta: Yayasan Ulul Arham 2002), hal. 79 kehidupan masyarakat. ${ }^{11}$

Dari sudut politik, orang tidak hanya melihat pada pelaksanaan hukum, akan tetapi juga mempertimbangkan akibat-akibat suatu keputusan yang berlandaskan hukum pada kepentingan bangsa dan Negara yang lebih luas. Kedua macam sikap dan pandangan itu acap kali menimbulkan keraguan dalam melaksanakan hukum di lapangan. Jadi sulit sekali bagi kita untuk memisahkan hukum, politik, dan ekonomi mengingat hukum merupakan produk bersama DPR (sekumpulan politisi) dengan pemerintah, walaupun sudah ada political will (kemauan politik) dari pemerintah untuk mengedepankan supremasi hukum, namun hal tersebut belumlah cukup dan mungkin hanya akan menjadi jargon-jargon politik, untuk itu diperlukan political action (aksi politik) yang nyata di lapangan, yang tentunya hal ini akan mendapat dukungan dari seluruh lapisan masyarakat.

Dalam qanun yang mengatur tentang pelarangan khalwat, ruang lingkup pelarangan sendiri adalah segala bentuk kegiatan, perbuatan dan keadaan yang mengarah kepada perbuatan zina. Tujuan pelarangan khalwat atau mesum adalah:

1. Menegakkan syari'at Islam dan adat istiadat yang berlaku dalam masyarakat di Provinsi Nanggroe Aceh Darussalam

2. Melindungi masyarakat dari berbagai bentuk kegiatan dan/ atau perbuatan yang merusak kehormatan

3. Mencegah anggota masyarakat

11 Soerjono Soekanto, Sosiologi Suatu Pengantar, (Jakarta: Raja Grafindo Persada, 2007), hal. 357 
sedini mungkin dari melakukan perbuatan yang mengarah kepada zina

4. Meningkatkan peran serta masyarakat dalam mencegah dan memberantas terjadinya perbuatan khalwat/mesum.

5. Menutup peluang terjadinya kerusakan moral.

Qanun No. 14 Tahun 2003 tentang Khalwat (Mesum), jika dilihat dari jenis perbuatan melawan hukumnya, bukan suatu hal yang baru. Hal yang sama ditemui dalam aturan kesusilaan yang ada dalam Kitab Undang-undang Hukum Pidana (KUHP). Terlepas dari kontroversi yang dimilikinya, KUHP produk Belanda ini telah mengatur permasalahan kesusilaan. Bahkan jauh lebih rinci dibanding Qanun Khalwat. Dalam Qanun khalwat didefinisikan sebagai perbuatan bersunyi-sunyi antara dua orang mukallaf 15 atau lebih yang berlainan jenis yang bukan muhrim atau tanpa ikatan perkawainan.

Sementara dalam KUHP, hal-hal kecil yang merupakan perbuatan asusila bahkan mendapat hukuman pidana. Dalam KUHP perbuatan asusila akan ditindak sebagai pelanggaran hukum ketika dilakukan di muka umum. Sementara jika dilakukan ditempat tertutup tidak lagi menjadi obyek hukum. Orientasi hukum pidana tentang pengaturan kesusilaan ini mengarah pada upaya melindungi orang lain untuk tidak terganggu atau terpengaruh oleh tindakan yang menyebabkan timbulnya birahi orang lain.

Namun demikian, keduanya tetap memiliki perbedaan orientasi hukum. Perbuatan khalwat akan tetap ditindak baik dilakukan di tempat umum (terbuka) maupun di tempat tertutup. Artinya, orientasi hukum pengaturan khalwat adalah untuk kemaslahatan pribadi seseorang dan juga orang lain. Manfaat pribadi agar seseorang tidak melakukan perbuatan yang mengarah pada perbuatan zina yang dilarang oleh agama dan mengakibatkan dosa dan siksa di kemudian hari. Sementara manfaat bagi orang lain adalah melindungi masyarakat dari berbagai bentuk kegiatan dan atau perbuatan yang merusak kehormatan. Sebagaimana dikemukakan pada Qanun khalwat, tujuan larangan khalwat salah satunya adalah melindungi masyarakat sedini mungkin dari melakukan perbuatan yang mengarah kepada zina dan merusak kehormatan.

Perlu diketahui sebagai catatan bahwa ada perbedaan yang sangat esensial mengenai definisi zina di dalam hukum positif Indonesia (KUHP) dengan hukum Islam. Di dalam Kitab Undangundang Hukum Pidana Indonesia pasal 284 dinyatakan bahwa zina adalah persetubuhan yang dilakukan oleh lakilaki atau perempuan yang telah kawin dengan perempuan atau laki-laki yang bukan istri atau suaminya. Dan supaya masuk pasal ini, maka persetubuhan itu harus dilakukan dengan suka sama suka, tidak boleh ada paksaan dari salah satu pihak. ${ }^{12}$

Kenyataan tersebut menunjukkan betapa jauh perbedaan antara hukum Islam dengan hukum positif. Walaupun sama-sama bertujuan untuk memelihara kepentingan dan ketenteraman masyarakat, serta menjamin kelangsungan hidup namun hukum Islam

12 R. Soesila, Kitab Undang-undang Hukum Pidana (KUHP), (Bogor: Politeia, t.t), hal. 181 
lebih memperhatikan soal akhlak, di mana tiap-tiap perbuatan yang bertentangan dengan akhlak yang tinggi tentu diancam hukuman. Akan tetapi tidak demikian halnya dengan hukum positif yang boleh dikatakan telah mengabaikan soal-soal akhlak sama sekali dan baru mengambil tindakan, apabila perbuatan tersebut membawa kerugian langsung bagi perorangan atau ketentuan masyarakat. ${ }^{13}$ Sebagai contoh adalah perbuatan zina. Hukum positif tidak menghukum perbuatan tersebut, kecuali apabila terjadi perkosaan terhadap salah satu pihak atau tanpa kerelaan salah satunya. Karena dalam keadaan demikian, perbuatan tersebut merugikan perorangan maupun ketenteraman umum. Akan tetapi syari'at menghukum perbuatan zina dalam keadaan dan bentuk bagaimanapun juga, karena zina dipandangnya bertentangan dengan akhlak dan apabila akhlak sudah rusak maka rusaklah masyarakat.

Yang menjadi sebuah catatan menarik, dalam beberapa kasus khalwat yang ditemukan di Aceh Utara, ternyata ada yang mengaku telah melakukan perbuatan zina. Artinya perbuatan mesum yang telah dilakukan si pelaku sudah bukan sekadar khalwat lagi, tapi telah melebihi dari tindakan amoral tersebut. Hanya saja karena qanun mengenai perzinaan ini belum diatur, maka kepada si pelaku hanya dikenakan qanun tentang khalwat. Dari sisi pandangan legal-formal, khususnya ditinjau dari asas-asas hukum pidana "konvensional", tindakan ini bisa dibenarkan karena sejalan dengan

13 Ahmad Hanafi, Asas-asas Hukum Pidana Islam, (Jakarta: Bulan Bintang, 1993), hal. 4 ungkapan Nullum Deliktum Nulla Poena Sine Praevia Lege Poenali (Nullum Crimen Nulla Poena Sine Lege), bahwa hukum hanya dapat menjatuhkan pidana terhadap perbuatan-perbuatan yang dilakukan setelah dinyatakan sebelumnya sebagai tindak pidana. Namun demikian, bila dikaji dari sisi asas legalitas hukum Islam, maka perbuatan zina sebenarnya telah menjadi ketentuan yang berlaku berabad-abad silam pada masa risalah Rasulullah Saw. Perbuatan haram ini dalam konteks hukum Islam dikategorikan sebagai bagian dari hudud (tindak pidana yang ketentuan hukumnya telah diatur dalam Nass).

Bersunyi-sunyi masih ditetapkan sebagai unsur sifat khalwat, di mana dalam hal ini masih mengikuti qitab-qitab fiqh. Dalam beberapa hal, definisi ini memang agak kontradiktif dengan kenyataan, sebab secara tekstual, definisi tersebut tidak menjerat nuansa khalwat yang kadang dilakukan secara terang-terangan yang disebut dengan pergaulan bebas. Praktikpraktik yang berbentuk pergaulan bebas ini banyak terlihat dalam keseharian, khususnya di wilayah Aceh Utara. Muda mudi yang berboncengan dengan rapat dan mesra di jalan-jalan raya, atau yang duduk berdua di warnet (warung internet), di kafekafe, pantai, dan tempat-tempat rekreasi, hal mana dari sikap dan tingkah lakunya dapat diduga bahwa mereka bukanlah pasangan suami istri.

Yang diharapkan dari penekanan terhadap sifat bersunyi-sunyi itu adalah dampaknya secara psikologis kepada masyarakat. Sesuai dengan ayat tentang larangan zina, yang dilarang secara langsung adalah mendekati zina. Perbuatan mendekati zina adalah khalwat itu sendiri, kerena itu khalwat adalah atau jalan 
kearah perzinahan. Logikanya, jika mendekati zina saja dilarang, maka melakukan zinanya pasti lebih terlarang.

Adapun unsur i'tikad jahat, memang dalam khalwat unsur itu sangat kentara. Para pelaku pasti sudah mengetahui bahwa pergaulan bebas atau penyelewengan bertentangan dengan ajaran agama dan adat istiadat, akan tetapi pekerjaan itu dilakukan juga, padahal agama sudah menyediakan lembaga pernikahan untuk menghalalkan hubungan suami istri, akan tetapi lembaga ini tidak dipergunakan. Dalam pelaksanaanya, walaupun khalwat adalah perbuatan seperti yang tertera di atas. Namun pemerintahan Aceh Utara melalui lembaga pelaksana syari'at Islam tetap memberikan pembatasan yang jelas dalam setiap kegiatan yang diadakan di Aceh Utara yang dapat diduga menjadi ajang mesum oleh muda-mudi. Seperti izin pengadaan kegiatan seni (konser musik dan lain-lain), agar dalam proses kegiatan tidak mencampur baurkan antara laki-laki dan perempuan atau dipisah.

Jika terjadi pelanggaran dalam kegiatan tersebut maka instansi terkait yang mengeluarkan izin dapat dengan seketika mencabut izin kegiatan dan membatalkan kegiatan seni tersebut dengan seketika. Begitu pula dengan usaha di bidang hiburan seperti teater tidak diperbolehkan beroperasi atau melakukan kegiatan usahanya sebelum adanya pengaturan yang jelas dari pemerintahan Aceh Utara.

\section{PENUTUP}

Keberadaan seorang pria dan wanita yang tidak ada hubungan kekerabatan sehingga halal menikahinya, di tempat yang sepi tanpa didampingi oleh mahram dari pihak laki-laki atau perempuan. Khalwat ini merupakan maksiat yang tidak dikenakan hukuman hudud dan hukuman kafarah. Bentuk tindak pidana khalwat ini termasuk dalam kategori jarimah ta'zir yang jumlah hukumannya tidak terbatas. Dalam alQur'an dan Sunnah perbuatan khalwat ini sangatlah dicela, tetapi tidak diatur secara jelas perihal hukumannya di dalam alQur'an dan Sunnah. Jadi perbuatan ini dapat dimasukkan ke dalam kelompok ta'zir. Semua perbuatan yang harus (perlu) dilarang guna memenuhi kemaslahatan umum (masyarakat). Pelarangan ini tentu harus dibuat berdasarkan kesepakatan/ musyawarah masyarakat dengan cara-cara yang dianggap memenuhi syarat. Aceh Utara, pelaku khalwat yang dekat dengan kekuasaan sulit sekali untuk disentuh dengan hukum, hal ini tidaklah mengherankan kita semua mengingat hukum di negeri ini belumlah menjadi panglima tapi hukum hanyalah sebagai posisi tawar menawar dalam kehidupan sehari-hari 


\section{DAFTAR PUSTAKA}

Abdul Aziz Dahlan, Ensiklopedi Hukum Islam, Jakarta: Ichtiar Baru van Hoeve, 1996

Abdullah bin Jarullah, Masuliyatul Marah al Muslimah, 2012

Idris Ramulyo, Asas-asas Hukum Islam. Jakarta: Sinar Grafika.2004

Abubakar Al Yasa', Penerapan Syariat Islam di Indonesia; Antara Peluang Dan Tantangan, Jakarta: Globamedia Cipta Publishing, 2004

Abubakar Al Yasa'dan Marah Halim., Hukum Pidana Islam di Nanggroe Aceh Darusalam, Dinas Syari'at Islam Nanggroe Aceh Darussalam, 2006

Ahmad Hanafi, Asas-asas Hukum Pidana Islam, Jakarta: Bulan Bintang, 1993

Al-hasyimi, mukhtarulahadits, bandung: Alma 'arif, 2000

Ibnu Hajar Ash-Qalani, Bulugh al-Maram, terj. KH. Kahar Masyhur, Jakarta: PT. Rineka Cipta, 1992

Ibnu Rusyd, Bidayah al-Mujtahid, Beirut - Libanon: Dar al-Kutub al-Islamiyah, t.t

Imam Taqiyuddin, Kifayah al-Akhyar, Beirut: Dar al-Kitab al-Alamin, 1995

M. Djali Yusuf, Perekat Hati yang Tercabik: jawaban atas Dinamika persoalan, Refleksi sosial Aceh, dan sebuah kesadaran untuk Masa Depan, Jakarta: Yayasan Ulul Arham, 2002

Nasrullah, Konsep Ancaman pidana Ta'zir Dalam Fiqih Syafi'iyyah (Analisis Terhadap Qanun NAD No. 14 Tahun 2003), Banda Aceh: Program Pasca Sarjana IAIN AR-RANIRY, 2006

R. Soesila, Kitab Undang-undang Hukum Pidana (KUHP), Bogor: Politeia, t.t

Sayyid Sabiq, Fiqh Sunnah, Jilid 9, Kuwait: Dar al-Bayan, 1968

Soerjono Soekanto, Sosiologi Suatu Pengantar, Jakarta: Raja Grafindo Persada, 2007.

120 Khalwat Dalam Perspektif Hukum Islam Dan Hukum Positif 